\title{
Discussion on Construction of College Student Party Branches
}

\author{
Xiaobo Liu \\ Xi'an Shiyou University, Xi'an Shaanxi, 710065, China
}

Keywords: Party construction; colleges and universities; student Party branch; construction

\begin{abstract}
A student Party branch is the most primary Party organization in a college or university, the core carrier to gather the college Party members, and the main base to educate and manage the members, which is responsible for the direct education, management and supervision of the Party members and the organization, publicity, gathering and service for the masses. Therefore, it is very important to research the constructive significance of the college student Party branches. By the analysis of the significance, the current situation and existing problems in the construction of college student Party branches, the author puts forward some research suggestions in order to continuously improve their creativity, cohesiveness and fighting capacity, so as to make them give full play to the role of the guidance and fighting fortress with their thought, and constantly train qualified constructers and reliable successors for the Party and the state.
\end{abstract}

\section{Introduction}

A student Party branch is the most primary Party organization in a college or university, the core carrier to gather the college Party members, and the main base to educate and manage the members, which is responsible for the direct education, management and supervision of the Party members and the organization, publicity, gathering and service for the masses. With the development of the times, the college students born after 1995 have become the main force in the college student groups. How to seriously analyze and think about the main problems in the construction of the college student Party branches, and continuously improve their creativity, cohesiveness and fighting capacity in order to make them give full play to the role of guidance and fighting fortress with their thought according to the characteristics of contemporary college students and the general requirements to strengthen and improve the Party construction, are the problems that our college Party constructors shall think about seriously.

\section{Constructive significance of college student Party branches}

Colleges and universities shoulder the important responsibility of training the reliable constructers and qualified successors for the socialism. As the most primary Party organizations in colleges and universities, the Party branches have the important responsibility of constantly supplying fresh blood to the development of the Party and the state.

\subsection{For the development of party members.}

In accordance with the Party constitution, where there are more than three Party members, a Party primary organization shall be established. According to the requirements for Party constitution, all colleges and universities have established their respective student Party branches to strengthen the management, training and role of student Party members, and constantly enhance their ideological awareness and Party spirit. Through the daily educational management and supervision for the Party members, the student Party branches drive the Party members to keep their advancement at all times and to learn the theoretical knowledge, policies, regulations and professional knowledge, in order to constantly improve their quality and play an exemplary and vanguard role.

\subsection{To reinforce the cohesiveness of the primary Party organizations.}

College Party branches are the primary organizations in colleges and universities, and the 
construction of Party branches is not only related to the quality development of Party members, but also related to the Party's rallying point, influence and cohesiveness for young people, especially the generation born after 1995 in the talent training in this diversified era. Colleges and universities are the bases of talent training. It is the all work and foundation for the college student Party branches to play the role of a primary party organization, insist on the leadership of the Party, hold high the great banner of the socialism with Chinese characteristics, condense the strength of the Party members, and continuously supply talents for the development of the Party and the state.

\subsection{To improve the Party's fighting capacity in the social primary organizations.}

"At any time, the Party will put the benefit of the masses at the first place, and share happiness and woe with the masses, and keep close ties with them." ${ }^{[1]}$ This is the Party's line for the masses. As the primary Party organizations, while persisting in serving the people wholeheartedly and publicizing and implementing the Party's lines, principles and policies actively, the college Party branches shall organize the party members to carry out the activity of "two-learning and one-being" (learn Party constitution and Party rules, learn series speeches, and be qualified Party members), learn Xi Jinping's important thought of socialism with Chinese characteristics in the new era, and keep pace with the times, so as to better discover and train excellent talents, constantly play their role of fighting fortress, and contribute to the development of our motherland!

\section{Current situation and existing problems in the construction of college student Party branches}

The college student Party branches shall continually reform and innovate with their own characteristics, show a state of vigorous development, and become the main base to carry forward the new fashion of socialism and the backbone for ideological guidance. It is true that the construction of Party branches is always on the road. It is necessary to understand the basic situation of the construction of college student Party branches at present and analyze the problems and difficulties in the construction, so as to make greater efforts to further improve the construction of Party branches.

\subsection{The establishment and problems of college student Party branches.}

In accordance with the requirements of the Party constitution, the establishment of college student Party branches is becoming perfect and standardized. Taking the establishment of the student Party branches in the schools and departments in our college as an example, most schools and departments establish the branches in grades, and some within respective major. However, because the number of the formal Party members in the junior grades is relatively small, and the number of the formal Party members in the senior grades is high but they are about to graduate, the personnel mobility is large, so the learning and educational effect of the branches in grades is possibly unsatisfactory due to the lack of the member of Party members and the guidance by the experienced Party members, and the branches established within respective major have some difficulties in the communication between the Party members due to different learning time of different grades. Moreover, it is difficult to carry out the education activities, and there are still some problems. Therefore, the rational establishment of branches is always a task worthy of continuous practice and research.

\subsection{The secretaries of college student Party branches have insufficient leadership.}

The role of the Party branch secretaries is particularly important for the construction of student Party branches. According to the appointment of Party branch secretaries in our college, it is common that student Party members serve as the branch secretaries over the years, but a realistic problem is that these student branch secretaries are lack of Party construction experience, and they are not trained systematically and perfectly, which leads to their insufficient theory and service ability. Therefore, in the work of the branches, there is a problem that the theory has lost the persuasiveness in the practice, and the student branch secretaries cannot fully play their roles in the condition of imperfect construction of the student branches. 


\subsection{The student Party branches are unable to carry out the enough education for the Party members.}

The college Party members are the main force for the Socialist Modernization, who shall have strict requirements for their behaviors, specialty literacy and comprehensive practical ability, and strive to improve their own quality and abilities continually, in order become the qualified constructer and ideological leaders. However, the fact is that most of the branch activities and the education for Party members are to cope with the examinations from senior organizations, which are formalistic, and there is no education activity that can really touch the Party members' hearts and enable them to carry out the learning practice spontaneously, so as to play an exemplary and vanguard role. Therefore, the overall quality of the Party members needs to be further improved.

\section{Some suggestions on construction of college student Party branches}

For the existing problems in the construction of Party branches, we need to continuously improve the management ability, strengthen the organization construction, reinforce the cohesiveness of the Party organizations, and especially carry out the educational management for the Party members well, in order to make them fully play the exemplary and vanguard role and drive the continuous development of our Party. According to the work experience, some suggestions are put forward for above problems:

\subsection{Strengthen the educational management and improve the Party members' quality with strict standard.}

The Party Central Committee has made it clear that the Party shall be managed and governed strictly and the Party construction shall be strengthened, and the Party members shall be developed according to the general requirements of "controlling the total amount, optimizing the structure, improving the quality and playing the role" ${ }^{[2]}$. Therefore, as the primary Party organizations, the Party branches shall control the relationship between the "quantity" and the "quality" correctly in the development process of student Party members. On the one hand, guarantee the development quality of Party members, make strict standards, set up the idea of quality first, and overcome the abnormal phenomenon of taking the number and proportion of student Party members developed as the assessment performance of subordinate Party organizations. On the other hand, while adhering to the quality development, actively attract the advanced students to close up to the Party organization, in order to ensure the continuous fresh blood for the Party.

There is a fashion of joining the Party in colleges and universities. Many students regard joining the Party as a weight for job hunting, and their motives to join the Party are impure. Therefore, the Party branches shall constantly strengthen the educational management and training of the activists of Party application and correct their motives to join the party in order to ensure the purity of the Party and the advancement of the Party members; establish the idea of continuing education and lifelong education, strengthen the whole education process for young students before and after entering the Party and in the process of entering the Party, and carefully examine the actual performance and progress of the activists of Party application, to really achieve the goal that every developed Party member is mature.

Besides, make good use of the working measures for the Party's criticism and self-criticism, pay attention to and give full play to the role of the supervisory mechanism, and take effective measures, such as regular informal discussion and questionnaire survey, so that the Party members can often be supervised and assessed by the masses. In addition, for the Party members' existing problems, the Party branches shall point out them in time and order them to correct the problems within limited time, so as to guarantee the development quality of Party members.

\subsection{Reinforce the cohesiveness of Party branches}

Reinforcing the cohesiveness of Party branches is an important content to promote the construction of Party branches and an important way to consolidate the ruling foundation of the Party. 
The cohesiveness produces the fighting capacity, and the unity produces the resultant force. Otherwise, the Party organization will be weak, lax and distracted, and the Party branches cannot play the role. Therefore, the general Party branch must attach importance to strengthening the cohesiveness of Party branches and continually reinforce it by all manner of means with the wisdom of the masses through various channels.

To reinforce the cohesiveness of Party branches, the fundamental guarantee is to carry forward the party's political advantage and strengthen the ideological and political work of the Party branches. We shall do well in education, management and supervision of the Party members, strengthen the Party members' Party spirit, and conscientiously maintain the unity of the Party. In a sense, a Party branch is a contradiction aggregation, mainly showing in the work and on the cognition and benefit. Therefore, the Party branches shall handle their internal contradictions correctly, and handle affairs practically in accordance with the Party constitution, so that everyone can be equal in front of the Party constitution and is convinced by reasoning.

To reinforce the cohesiveness of Party branches, we must insist on and perfect the Party's basic organizational system, leadership system and democratic centralism. To realize that "the democracy within the Party is the life of the Party, which plays an important exemplary role for people's democracy" [3], we mush establish and improve the democracy within the Party to ensure the democratic rights of the Party members and fully reflect the Party members' will. On some principles, the Party branches must be highly consistent. For the achievement that "all Party comrades must consciously adhere to the principles that individuals obey the organization, the minority obeys the majority, the subordinate organizations obey the superior organizations, the whole party obeys the National Party Congress and the Central Committee, and firmly maintain the absolute authority of the Party Central Committee to guarantee the Central Committee's political orders are unimpeded" [4], we must ensure the cohesiveness of Party branches with the system and the Party's disciplines. Moreover, it is an important measure to carry forward the democracy and carry out the criticism and self-criticism on the work of the Party branches and Party members with the effective carriers, such as the organizational life meeting, democratic life meeting and democratic assessment. However, the current criticism and self-criticism are unsatisfactory and even has little effect. Therefore, we shall study and explore the current situation as soon as possible and put forward some new ideas, in order to continue to carry forward the Party's fine style.

To reinforce the cohesiveness of Party branches, the key is to play the role of the minority, namely, the Party branch secretaries and committees. The Party branch secretaries shall constantly improve their own political attainments and leadership, show their personal charm, influence and drive all Party members to carry out the work to form a situation of all response to a command, respect all Party members, set an example of unity, care for the Party members' thought, learning, work and life, and try to help them deal with the troubles. The members of the Party branch Committee shall trust each other and support each other, put the Party's cause at the first place, and assist in forming the core of cohesiveness.

\subsection{Create new forms, enhance vitality and improve the life quality of the Party branches}

Adhere to the system of "three meetings and one class" (the meeting of all branch Party members, the branch committee meeting, the group Party meeting and the party class), which is the basic work for the primary Party organizations and the main educational management form for the Party members. In according to the requirements of the superior Party organization for the work, the college Party branches shall carry out and organize the life that meets the requirements of systematization, standardization and democratization basically, make plans and tasks regularly at fixed points, and play the role of learning, education, training, management and supervision basically. However, the life form organized by the Party branches is formalistic with poor content, which mainly is to read the documents, and the minority of Party members disagree with the organization life, and don't participate in the life actively with resistance and liberalism, which influence the party members on playing their creativity and influence the whole branch on playing the fighting capacity. 
Therefore, we shall constantly create new Party branch life with innovative idea, open content, diverse forms, and democratic and interactive process. The organizational forms can be centralized and dispersed at the same time. For example, translate the past massed learning (or meeting) to visiting, investigation, skill competition, social practice, Party branch construction, policy symposium and so on, and even carry out some recreational and sports activities to improve the attraction of the branch organization life. The Party branch secretaries shall do a good job in the task with key points based on investigation, and can solve one or two problems. In the organization life, we shall pay attention to guiding the Party members to discuss the central topic, avoid the boundless discussion, and prevent the Party members' enthusiasm from being damaged, to guarantee the life quality of the Party branch organizations.

\section{Conclusion}

The construction of Party branches is always on the road. Especially the college student Party branches which are facing the most active and leading-edge student groups shall constantly research and create new work forms and contents and reinforce the vitality and cohesiveness of the Party branches, in order to attract many young students to move closer to the Party organization, and train and supply qualified constructers and reliable successors to the Party and the state.

\section{References}

[1] Be a Qualified Communist, Beijing: People's Publishing House, 2016.

[2] Subsidiary Book for Report of the 18th National Congress of the CPC, Beijing: People's Publishing House, 2012.

[3] Wang Zhewei, Some Opinions on Current Construction of College Student Party Branches, Leading Journal of Ideological \& Theoretical Education, 2011 (3).

[4] Guidance for Learning Party Constitution and Rules, Beijing: People's Publishing House, 2016. 